\title{
MICROPROPAGATION OF WILD ARTEMISIA JUDAICA L. GROWING IN SINAI
}

\author{
Mahmoud M.A., El-Mekawey, M.A. and Hassan, H.M.S. \\ Dept. Plant Production, Faculty of Environ. Agri. Sc., Suez Canal University, Egypt.
}

\begin{abstract}
This study was carried out in Plant Tissue Culture Laboratory in Faculty of Environmental Agricultural Sciences (FEAS) El-Arish, North Sinai, Suez Canal University (SCU) during the period from 2012 to 2014. The objective of this study was to propagate Artemisia judaica L. by using tissue culture technique. The results indicated that BA at $1.0 \mathrm{mgl}^{-1}$ with NAA 0.1 $\mathrm{mgl}^{-1}$ gave the highest values of number of axillary shoots/explant (2.0 shoots/explant), axillary shoot length and highest number of leaves/shoot. Also, MS media produced the highest number of axillary shoots/explants and axillary shoot length followed by Chee and Pool medium. The highest number of leaves/shoot was recorded with MS media supplemented with BA at $1.0 \mathrm{mgl}^{-1}$ combined with $0.1 \mathrm{mgl}^{-1} \mathrm{NAA}$. Addition of casein hydrolysate at $2.0 \mathrm{gl}^{-1}$ combined with BA at $1.0 \mathrm{mgl}^{-1}+\mathrm{NAA}$ at $0.1 \mathrm{mgl}^{-1}$ increased No. of axillary shoots and No. of leaves/shoot. Callus fresh weight was increased with the combination of $2.0 \mathrm{mgl}^{-1}$ 2,4-D and $0.2 \mathrm{mgl}^{-1}$ kinetin after four subcultures. MS basal medium supplemented with $1.0 \mathrm{mgl}^{-1}$ NAA produced increase in No. of roots and No. of leaves/plantlet. Addition of IBA at $1.5 \mathrm{mgl}^{-1}$ recorded the highest values of all rooting parameters. Plantlets were successfully acclimatized in mixture of peat moss and sand $(3: 1$, $\mathrm{v} / \mathrm{v})$.
\end{abstract}

Key words: Artemisia judaica L., stem node, tissue culture technique, BA, 2,4-D, NAA, IBA, callus, MS media and kinetin.

\section{INTRODUCTION}

Artemisia judaica L. plant belongs to family Compositae (Asteraceae) is an Egyptian medicinal plant. It is an important specie since it is a source of active substances which can be used for several medicinal and other purposes.

In medicinal uses, the leaves, and especially the essential oil contained in them, are strongly antiseptic, deodorant and disinfectant. It is also used as treatment for gastrointestinal disorders (Huxley, 1992 and Bown, 1995). The essential oil is also used in manufecture of perfumery and soaps, as a mouth wash flavoring baked goods, condiments, beverages and ice creams etc. (Facciola, 1990 and Bown, 1995).

Many plant species such as Artemisia judica and Artemisia monosperma are capable to grow under the aridity conditions at Wadi Wateer area. Some species of medicinal and aromatic plants are disappearing gradually from Sinai natural environment. Artemisia judaica L. is one of these endangered plants. So, to face this problem tissue culture technique can be used Micropropagation has become one of the most ways reproducing crops 
that are difficult to propagate by conventional method such as seeds or cuttings. Micropropagation allows the production of large number of plants in a relatively small growing area and in a relatively shorter time (Nizar, 2001).

The main objective of this study was to establish an applicable protocol to propagate this endangered species through in vitro micropropagation of this plant.Banerjee et al. (2010) on Artemisia roxburghiana found that, maximum of 38 \pm 0.87 shoots per explant could be obtained after 6 weeks of incubation. Subculturing of the shoot mass after 8 weeks of culture on $8.88 \mathrm{lM}$ BA and 0.27 IM NAA containing medium stimulated further multiplication.

Hristova et al. (2013) on
micropropagation of Artemisia
chamaemelifolia showed that, the middle
concentrations of $0.5,0.6$ and $0.7 \mathrm{mg} / \mathrm{l}^{-1}$
BA gave the highest number of shoots.
Ndoye et al. (2003) on Balanitesa
egyptiaca they stated that, kin was found
to be less effective than BAP and $2.5 \mathrm{mgl} 1^{-}$
${ }^{1}$ BAP in combination with $0.1 \mathrm{mgl}^{-1} \mathrm{NAA}$
or IAA was the most effective combination
for axillary bud multiplication.

Ahmed et al. (2005) on Phyla nodiflora L. found that, the maximum number of shoots were found on MS medium supplemented with $2.5 \mathrm{mgl}^{-1}$ 6benzylaminopurine and $0.5 \mathrm{mgl}^{-1}$ kinetin. He et al. (2005) standardized an efficient plant regeneration system for Aquilaria agallocha from shoots developed from seedlings as shoots generated many buds on MS medium supplemented with 1.3 $\mu \mathrm{mol} / 1 \mathrm{BA}$.

Faisal et al. (2006) on Mucuna pruriens plant found that, BA at an optimal concentration of $5.0 \mu \mathrm{M}$ was the most effective in inducing multiple shoots. Nishawy (2008) found that culturing Thymus capitatus stem node sections on
Murashige and Skoog basal medium supplemented with $0.5 \mathrm{mgl}^{-1} \mathrm{BA}$ was the most suitable medium for increasing the number of axillary shoots and leaflet number. However, the concentration of $1.0 \mathrm{mgl}^{-1}$ was the most promising treatment in response to length of axillary shoots, length of shoot and node number.

Hassanein et al. (2008) cultured shoottip of Capparis cartilaginea on MS medium containing $0.10 \mathrm{mgl}^{-1} \mathrm{NAA}+$ $3.00 \mathrm{mgl}^{-1}$ BA and recorded that this medium gave the highest percentage of survival $(100 \%)$, axillary shoot formation (76.74 \%), mean number (3.20) and length $(0.564 \mathrm{~cm})$ of axillary shoots per explants. Nathar and Yatoo (2014) found that, the highest number of Artemisia pallens shoots and shoot length were observed on MS medium supplemented with $3.0 \mathrm{mgl}^{-1}$ kinetin after 40 days.

\section{MATERIALS AND METHODS}

This study was carried out in Plant Tissue Culture Laboratory, Faculty of Environmental Agricultural Sciences (FEAS) El-Arish, North Sinai, Suez Canal University (SCU) during the period from 2012 to 2014.

The objective of this study was to propagate endangered wild species, Artemisia judaica $\mathrm{L}$ growing in Sinai Peninsula by using tissue culture technique.

\section{Direct regeneration:}

Artemisia judaica L. shoots of one year old obtained from herbal perennial plants were collocated from North Sinai Research Station (El-Sheikh Zuwyed) Experimental Farm, Desert Research Center (DRC), Mataria, Cairo, Egypt. Stem nodal explants $(0.5-1.0 \mathrm{~cm}$ length) were excised from shoots and used as an explant in establishment stage .Explants have been washed under a running tap water for $1 \mathrm{~h}$. before submerging then in 
water with a few drops of liquid detergent in a flask and shaking them by hand for 15 min then rinsed in tap water to remove the soap. Explants were sterilized with $70 \%$ ethanol for 30 seconds them washed with sterile distilled water before the explants were transferred to the laminar air flow hood and treated with $30 \%$ solution (v/v) commercial clorox for 20 minutes then rinsed with sterile distilled water.

\section{Culture medium preparation:}

The sterilized nodal explants were cultured on MS medium (Murashige and Skoog, 1962) solidified with agar at $8 \mathrm{gl}^{-}$ ${ }^{1}$ and supplemented with glycin $\left(2 \mathrm{mgl}^{-1}\right)$, Myo-inositol $\left(0.1 \mathrm{gl}^{-1}\right)$ and sucrose $\left(30 \mathrm{gl}^{-1}\right)$. Medium was supplemented with different concentrations $\left(0.0,0.5,1.0\right.$ or $\left.1.5 \mathrm{mgl}^{-1}\right)$ of benzyl adenine (BA) or kinetin (kin) combined with $0.1 \mathrm{mgl}^{-1} \mathrm{NAA}$. $\mathrm{pH}$ of the medium was adjusted at 5.7- 5.8.The medium was cooked then distributed into the culture jars. Each jar contained $50 \mathrm{ml}$ of the medium and the jars were immediately autoclaved at $121 \mathrm{C}^{\circ}$ and $1.1 \mathrm{Kg} \mathrm{cm}^{2}$ for $20 \mathrm{~min}$.

During multiplication stage the following types of media were investigated Murashige and Skoog medium (Murashige and Skoog, 1962), Murashige and Skoog shoot multiplication medium B, (Huang et al., 1976), Gamborg B5 medium (Gamborg et al., 1968, Chee and Pool (C2D) vitis medium (Chee and Pool, 1987) or Mccown woody plant medium (Lloyed and Mccown, 1980).

The cultures were incubated in growth room at $25 \pm 2 \mathrm{C}^{\mathrm{O}}$ under $16 \mathrm{~h} /$ day photoperiod which provided by cool white fluorescent lamps with light intensity of 2000 Lux. Different concentrations (0.0, $1.0,2.0$ and $4.0 \mathrm{gl}^{-1}$ ) of Casein hydrolysate either alone or combined with $1.0 \mathrm{mgl}^{-1}$ BA and $0.1 \mathrm{mgl}^{-1}$ NAA were investigated during this stage.

\section{Indirect regeneration:Artemisia judaica $\mathbf{L}$.}

young leaves were collected from shoots of one year old perennial plants growing in North Sinai Research Station (El-Sheikh Zuwyed) Experimental Farm, Desert Research Center (DRC), Mataria, Cairo, Egypt. The leaves were washed under a running tap water for one $h$. then explants were submerged in water with a few drops of liquid detergent in a flask and shacked by hand for $15 \mathrm{~min}$ then rinsed in tap water to remove the soap.

The explants were sterilized with $70 \%$ ethanol for 30 seconds and washed with sterile distilled water. Number of axillary shoots/explants, main shoot length $(\mathrm{cm})$, axillary shoots length $(\mathrm{cm})$ and No. of leaves/shoot were recorded after six weeks from incubation date for all above mentioned experiments.

\section{Callus formation and differentiation:}

In order to induce of callus leaf explants were cultured on MS medium supplemented with $2,4-\mathrm{D}$ at $0.0,1.0$ or $2.0 \mathrm{mgl}^{-1}$ or kinetin at $0.0,0.1,0.2$ or 0.3 $\mathrm{mgl}^{-1}$ Produced callus was re-cultured on the same medium three times (every 4 weeks) callus fresh weight (gm) was measured at the end of subculture.

For callus differentiation four week old callus were cut into small pieces 0.4 gm and cultured on MS supplemented with different concentrations of NAA $\left(0.0,1.0\right.$ and $\left.2.0 \mathrm{mgl}^{-1}\right)$ or kinetin $(0.0,0.1$ and $\left.0.2 \mathrm{mgl}^{-1}\right)$. After 4 weeks No. of shoots/calli, No. of roots/shoots, shoot length $(\mathrm{cm})$ and No. of leaves/ shoot were recorded.Similar shoots of Artemisia judaica L. (about 2-3 cm length) obtained direct or indirect regeneration experiments were cultured on MS medium supplemented with different concentrations $(0.0,0.5,1.0,1.5$ and 2.0 $\mathrm{mgl}^{-1}$ ) of indole acetic acid (IAA), indole butyric acid (IBA) or naphthalene acetic acid (NAA) with or without $1.0 \mathrm{gl}^{-1}$ 
activated charcoal After 4 weeks rooting percentage No. of roots/ shoots and root length $(\mathrm{cm})$ were recorded Rooted shoots (about 3-4 cm length) were acclimatized by transferring them to polyethylene bags containing peat moss and sand $(3: 1, \mathrm{v} / \mathrm{v})$. The cultured bags were covered with transparent polyethylene bags. After one week holes were made in covered bags. These holes were expanded gradually each week. After four weeks plantlets became suitable for transferring to the outside of green house. Experimental design and statistical analysis:

Experiments were set up in complete randomized design (CRD). There were four replicates and each replicate contained 4 jars. All collected data were analyzed with analysis of variance (ANOVA) procedure using MSTAT-C Statistical Software Package (Michigan State University, 1983). Differences between means were compared by using Duncan's multiple range test (Duncan, 1955).

\section{RESULTS AND DISCUSSION}

This study was mainly concerned to establish an applicable protocol to save the endangered native egyptian Artemisia judaica L. through in vitro micropropagation.

\section{Direct regeneration:}

This part of study was mainly designed to study the effect of growth regulators, medium type and casein hyrolysate on multiplication stages. Artemisia judaica L. shoot proliferation and growth during establishment and multiplication stages.

Effect of growth regulators on Artemisia judaica L. shoot proliferation and growth during establishment stage:

The effect of different BA and Kin concentrations combined with NAA at 0.1 $\mathrm{mgl}^{-1}$ on number of axillary shoots/explant are presented in (Table 1). Data cleared that addition of $\mathrm{BA}$ or kin to the medium contained $0.1 \mathrm{mgl}^{-1}$ NAA did not result in significant increase in no. of shoots per explant except with the treatment of 1.0 $\mathrm{mgl}^{-1}$ BA. Moreover, there are no significant differences between different concentrations of BA or kin.

This result was in agreement with Hristova et al. (2013) on Artemisia chamaemelifolia showed that, the middle concentrations of $0.5,0.6$ and $0.7 \mathrm{mgl}^{-1}$ BA gave the highest number of shoots/explant.

Also, the longest axillary shoot $(3.60$ $\mathrm{cm})$ was obtained with BA at $1.0 \mathrm{mgl}^{-1}$ combined with $0.1 \mathrm{mgl}^{-1} \mathrm{NAA}$.

The highest number of leaves/shoot was obtained with 1.0 or $1.5 \mathrm{mgl}^{-1} \mathrm{BA}$ or kin combined with $0.1 \mathrm{mgl}^{-1} \mathrm{NAA}$ without significant differences between these treatments. The tallest main shoot was belonged to BA at $1.0 \mathrm{mgl}^{-1}$ combined with $0.1 \mathrm{mgl}^{-1} \mathrm{NAA}$.

This result was in a harmony with Nishawy (2008) who found that Murashige and Skoog basal medium supplemented with $0.5 \mathrm{mgl}^{-1} \mathrm{BA}$ was the most suitable medium for shoot multiplication and leaflet number of Thymus capitatus. However, the concentration of $1.0 \mathrm{mgl}^{-1}$ was the most promising treatment for increasing the length of axillary shoots, length of shoot and node number.

On other plant, Hassanein et al. (2008) found that culturing of shoot-tip of Capparis cartilaginea on MS medium containing $0.10 \mathrm{mgl}^{-1} \mathrm{NAA}+3.00 \mathrm{mgl}^{-1}$ BA gave the highest percentage of survival $(100 \%)$, axillary shoot formation (76.74\%), mean number (3.20) and length $(0.564 \mathrm{~cm})$ of axillary shoots per explant. 
Table (1): Effect of growth regulators on Artemisia judaica L. shoot proliferation and growth during establishment stage.

\begin{tabular}{|c|c|c|c|c|c|c|}
\hline \multicolumn{3}{|c|}{ Growth regulators $\left(\mathrm{mgl}^{-1}\right)$} & \multirow{2}{*}{$\begin{array}{l}\text { No. of } \\
\text { axillary } \\
\text { shoots/ } \\
\text { explant }\end{array}$} & \multirow{2}{*}{$\begin{array}{l}\text { Axillary shoot } \\
\text { length }(\mathrm{cm})\end{array}$} & \multirow{2}{*}{$\begin{array}{c}\text { No .of } \\
\text { Leaves /shoot }\end{array}$} & \multirow{2}{*}{$\begin{array}{l}\text { Main shoot } \\
\text { Length (cm }\end{array}$} \\
\hline Kin & BA & NAA & & & & \\
\hline 0.0 & 0.0 & 0.1 & $1.00 \mathrm{~b}$ & $2.13 \mathrm{~b}$ & $5.33 \mathrm{c}$ & $2.66 \mathrm{c}$ \\
\hline 0.5 & 0.0 & 0.1 & $1.33 \mathrm{ab}$ & $2.03 \mathrm{~b}$ & $6.00 \mathrm{bc}$ & $2.76 \mathrm{bc}$ \\
\hline 1.0 & 0.0 & 0.1 & $1.66 \mathrm{ab}$ & $2.35 \mathrm{~b}$ & $7.33 \mathrm{ab}$ & $3.13 \mathrm{bc}$ \\
\hline 1.5 & 0.0 & 0.1 & $1.33 \mathrm{ab}$ & $2.45 \mathrm{~b}$ & $6.66 \mathrm{ab}$ & $2.96 \mathrm{bc}$ \\
\hline 0.0 & 0.5 & 0.1 & $1.33 \mathrm{ab}$ & $2.26 \mathrm{~b}$ & $5.33 \mathrm{c}$ & $2.73 \mathrm{c}$ \\
\hline 0.0 & 1.0 & 0.1 & $2.00 \mathrm{a}$ & $3.60 \mathrm{a}$ & $8.00 \mathrm{a}$ & $4.93 \mathrm{a}$ \\
\hline 0.0 & 1.5 & 0.1 & $1.33 \mathrm{ab}$ & $2.73 \mathrm{~b}$ & $7.00 \mathrm{ab}$ & $3.46 \mathrm{~b}$ \\
\hline
\end{tabular}

Means having the same letter (s) within the same column are not significantly different according to Dunchan's

multiple range test at $5 \%$ level of probability

Effect of media types and growth regulators on shoot growth and multiplication of Artemisia judaica $\mathrm{L}$. during multiplication stage:

The main effect of different media types supplemented with BA at $1.0 \mathrm{mgl}^{-1}$ combined with $0.1 \mathrm{mgl}^{-1} \mathrm{NAA}$ on shoot growth and multiplication of Artemisia judaica L. is illustrated in Table 2.The data showed that, there is no significant differences between all media types supplemented with BA at $1.0 \mathrm{mgl}^{-1}$ combined with $0.1 \mathrm{mgl}^{-1} \mathrm{NAA}$ on the number of axillary shoots/explant. MS and B5 media gave the highest axillary shoot length (3.60 and $2.73 \mathrm{~cm}$, respectively) without significant difference between both of them. There was also no significant differences between Murashige and Skoog multiplication B, B5, Chee and Pool or Mccown media in this concern.

Also, data presented in Table (2) demonstrated that the highest significant number of leaves/shoot (12.00 leaves/shoot) was recorded with MS medium supplemented with BA at $1 \mathrm{mgl}^{-1}$ combined with $0.1 \mathrm{mgl}^{1} \mathrm{NAA}$ compared with the other media types under study. In the second order came Chee and Pool medium (9.33 leaves/shoot) and in the third and fourth orders, same B5 and McCown Woody Plant Medium since both of them gave the same leaf number (8.00 leaves/shoot). On the other hand, MS medium produced the highest significant shoot length $(4.93 \mathrm{~cm})$ compared with the other media.

The obtained results are in harmony with Alasania et al. (2007) exploited Gamborg (B5) and MS nutrient media have been for in vitro propagation of endemic grapevine cultivar "Chkhaveri".

They found that MS cultivation medium supplemented with $8 \mu \mathrm{M}$ BAP solution turned out to be the optimum for propagation of grapevine explants. Sivanesan (2007) on Withania somnifera, tested different media like MS, B5 and SH and recorded that among the different tested media, MS supplemented with BAP was found to be the better medium compared to B5 and $\mathrm{SH}$ media. 
Table (2): Effect of medium type on Artemisia judaica L. shoot growth and multiplication during multiplication stage

\begin{tabular}{ccccc}
\hline Medium Type & $\begin{array}{c}\text { No. of axillary } \\
\text { shoots/ explant }\end{array}$ & $\begin{array}{c}\text { axillary shoot } \\
\text { length }(\mathbf{c m})\end{array}$ & $\begin{array}{c}\text { No. of } \\
\text { leaves/shoot }\end{array}$ & $\begin{array}{c}\text { Main shoot } \\
\text { Length(cm) }\end{array}$ \\
\hline MS & $2.33 \mathrm{a}$ & $3.60 \mathrm{a}$ & $12.00 \mathrm{a}$ & $4.93 \mathrm{a}$ \\
\hline $\begin{array}{c}\text { Murashige and Skoog } \\
\text { Multiplication B }\end{array}$ & $1.33 \mathrm{a}$ & $2.27 \mathrm{~b}$ & $5.33 \mathrm{~d}$ & $2.73 \mathrm{~b}$ \\
\hline B5 & $1.33 \mathrm{a}$ & $2.73 \mathrm{ab}$ & $8.00 \mathrm{c}$ & $3.46 \mathrm{~b}$ \\
\hline Chee and Pool & $1.66 \mathrm{a}$ & $2.56 \mathrm{~b}$ & $9.33 \mathrm{~b}$ & $3.53 \mathrm{~b}$ \\
\hline McCown & $1.33 \mathrm{a}$ & $2.43 \mathrm{~b}$ & $8.00 \mathrm{c}$ & $3.23 \mathrm{~b}$ \\
\hline
\end{tabular}

Means having the same letter (s) within the same column are not significantly different according to Dunchan's multiple range test at $5 \%$ level of probability.

Effect of casein hydrolysate concentration combined with $B A$ and NAA on growth of Artemisia judaica $\mathrm{L}$. during multiplication stage:

The main effect of different casein hydrolysate concentrations combined with $\mathrm{BA}$ at $1.0 \mathrm{mgl}^{-1}$ and $0.1 \mathrm{mgl}^{-1} \mathrm{NAA}$ on shoot growth and multiplication of Artemisia judaica L. was illustrated in Table (3).

Data illustrated that, there is no significant effect for casein hydrolysate either combined alone or combination with BA at $1.0 \mathrm{mgl}^{-1}+\mathrm{NAA}$ at $0.1 \mathrm{mgl}^{-1}$ on all studied parameters.

\section{Indirect regeneration:}

\section{Callus formation:}

Effect of kinetin (kin) concentration and number of subcultures on callus fresh weight of Artemisia judaica L.:

The main effect of kin concentrations on callus formation showed that increasing of kin concentration resulted in significant increase in callus weight Table (4). Also, callus weight was enhanced by increasing the number of subcultures.
The maximum callus weight was obtained with $0.2 \mathrm{mgl}^{-1} \mathrm{kin}$ at the fourth subculture. Similar results were obtained by Halaweish and Tallamy (1998) since they found that 2,4-D and kinetin supported the best callus weights from Cucurbita andreana and Cucurbita maxima hybrid were recorded with the concentrations of 2.0 and $1.0 \mathrm{mgl}^{-1}$, respectively.

Effect of 2,4-D concentration and number of subcultures on callus fresh weight of Artemisia judaica L.:

The main effect of 2,4-D concentration on callus fresh weight show that addition of 2,4-D to the medium resulted in significant increase in callus fresh weight without significant difference between both concentrations Table (5).

Data also show that callus weight was gradually enhanced with increasing the number of subcultures. The best callus fresh weight was obtained with addition of $2.0 \mathrm{mgl}^{-1}$ 2,4-D after the fourth subculture (32.98 gm) The obtained results are in a harmony with Shehata (2005) who found that the best callus fresh weight and callus index were obtained with $2.0 \mathrm{mgl}^{-1} 2,4-\mathrm{D}$, 
Table (3): Effect of casein hydrolysate $(\mathrm{CH})$ concentration alone or combined with $1.0 \mathrm{mgl}^{-1} \mathrm{BA}$ and $0.1 \mathrm{mgl}^{-1} \mathrm{NAA}$ on shoot growth and multiplication of Artemisia judaica L.during multiplication stage.

\begin{tabular}{ccccc}
\hline $\begin{array}{c}\text { Characters } \\
\text { Treatments }\end{array}$ & $\begin{array}{c}\text { No. of axillary } \\
\text { Shoots /explant }\end{array}$ & $\begin{array}{c}\text { Main shoot } \\
\text { length(cm) }\end{array}$ & $\begin{array}{c}\text { axillary shoot } \\
\text { length (cm) }\end{array}$ & $\begin{array}{l}\text { No. of } \\
\text { leaves/shoot }\end{array}$ \\
\hline Without $\mathbf{C H}$ & $1.33 \mathrm{a}$ & $2.93 \mathrm{a}$ & $2.53 \mathrm{a}$ & $4.33 \mathrm{a}$ \\
$\mathbf{1} \mathbf{~ g l}^{-1} \mathbf{C H}$ & $1.44 \mathrm{a}$ & $2.83 \mathrm{a}$ & $2.40 \mathrm{a}$ & $4.66 \mathrm{a}$ \\
$\mathbf{2} \mathbf{~ g l}^{-1} \mathbf{C H}$ & $1.66 \mathrm{a}$ & $2.96 \mathrm{a}$ & $2.50 \mathrm{a}$ & $4.66 \mathrm{a}$ \\
$\mathbf{4} \mathbf{~ g l}^{-1} \mathbf{C H}$ & $1.66 \mathrm{a}$ & $2.63 \mathrm{a}$ & $2.16 \mathrm{a}$ & $4.33 \mathrm{a}$ \\
$\mathbf{B A}+\mathbf{N A A}+\mathbf{W i t h o u t} \mathbf{C H}$ & $2.00 \mathrm{a}$ & $3.10 \mathrm{a}$ & $2.53 \mathrm{a}$ & $4.66 \mathrm{a}$ \\
$\mathbf{B A}+\mathbf{N A A}+\mathbf{1} \mathbf{~ g l}^{-\mathbf{1}} \mathbf{C H}$ & $2.00 \mathrm{a}$ & $3.06 \mathrm{a}$ & $2.63 \mathrm{a}$ & $4.66 \mathrm{a}$ \\
$\mathbf{B A}+\mathbf{N A A}+\mathbf{2} \mathbf{g l}^{-\mathbf{1}} \mathbf{C H}$ & $2.33 \mathrm{a}$ & $3.23 \mathrm{a}$ & $2.73 \mathrm{a}$ & $5.33 \mathrm{a}$ \\
$\mathbf{B A}+\mathbf{N A A}+\mathbf{4} \mathbf{~ g l}^{-\mathbf{1}} \mathbf{C H}$ & $1.66 \mathrm{a}$ & $3.01 \mathrm{a}$ & $2.53 \mathrm{a}$ & $5.00 \mathrm{a}$ \\
\hline
\end{tabular}

Means having the same letter (s) within the same column are not significantly different according to Dunchan's multiple range test at $5 \%$ level of probability

$0.1 \mathrm{mgl}^{-1}$ kin and the combination between them in both tested species (Achillea fragrantissima and Ecballium elaterium). Also, Thao et al. (2003) concluded that the highest percentage $(71 \%)$ of explants produced callus of Alocasia michlitziana was obtained on MS medium supplemented with $0.1 \mathrm{mgl}^{-1}$ 2,4-D and $0.1 \mathrm{mgl}^{-1}$ kin in the dark after 4 months of culture. Same results were obtained by Romano (1999) who reported that, callus initiation was observed from leaf explants of Dittrichia viscose cultured on B5 medium supplemented with $1.0 \mathrm{mgl}^{-1} 2,4-$ $\mathrm{D}$ and $0.1 \mathrm{mgl}^{-1} \mathrm{Kin}$.

Also, Azza and Noga (2002) induced callus from hypocotyl and primary leaf explants of cumin (Cuminum cyminum L.) seedling on a medium supplemented with $0.8 \mathrm{mgl}^{-1} 2,4-\mathrm{D}$ alone or with combination of 0.4 and $0.8 \mathrm{mgl}^{-1} \mathrm{Kin}$.

They reported that, in the presence of Kin and 2,4-D in the callus induction medium, higher percentage of the explants produced callus. Moreover Shehata (2005) reported that the best callus fresh weight and callus index were obtained with $2.0 \mathrm{mgl}^{-1} 2,4-\mathrm{D}, 0.1 \mathrm{mgl}^{-1} \mathrm{kin}$ and the combination between them in Achillea fragrantissima and Ecballium elaterium.

\section{Callus differentiation}

Effect of interaction between kinetin (kin) and $\alpha-$ naphthalene acetic acid (NAA) concentrations on callus differentiation of Artemisia judaica L.:

Data illustrated in Table (7) presented the effect of kin concentration on differentiation of Artemisia judaica L. callus.

Addition of kinetin alone to the culture medium significantly increased all recorded parameters. MS basal medium supplemented with $0.1 \mathrm{mgl}^{-1}$ kin gave the best values of shoot number and shoot length parameters. However, addition of kinetin at $0.2 \mathrm{mgl}^{-1}$ recorded the best values of number of roots and leaves. 
Table (4): Effect of kinetin concentration and number of subcultures on callus fresh weight (gm) of Artemisia judaica L.

\begin{tabular}{cccccc}
\hline $\begin{array}{c}\text { Kin } \\
\left(\mathbf{m g l}^{-1}\right)\end{array}$ & 1 & 2 & 3 & 4 & Means \\
\hline $\mathbf{0 . 0}$ & $0.44 \mathrm{~h}$ & $2.77 \mathrm{~g}$ & $2.72 \mathrm{~g}$ & $16.33 \mathrm{c}$ & $5.57 \mathrm{C}$ \\
$\mathbf{0 . 1}$ & $0.50 \mathrm{~h}$ & $3.55 \mathrm{fg}$ & $9.87 \mathrm{e}$ & $20.56 \mathrm{~b}$ & $8.62 \mathrm{~B}$ \\
$\mathbf{0 . 2}$ & $0.65 \mathrm{~h}$ & $4.56 \mathrm{f}$ & $13.32 \mathrm{~d}$ & $25.66 \mathrm{a}$ & $11.04 \mathrm{~A}$ \\
$\mathbf{0 . 3}$ & $0.57 \mathrm{~h}$ & $3.66 \mathrm{fg}$ & $10.21 \mathrm{e}$ & $21.14 \mathrm{~b}$ & $8.89 \mathrm{~B}$ \\
Means & $0.54 \mathrm{D}$ & $3.63 \mathrm{C}$ & $9.03 \mathrm{~B}$ & $20.92 \mathrm{~A}$ & \\
& & & & &
\end{tabular}

Table (5): Effect of 2,4-D concentration and number of subcultures on callus fresh weight (gm) of Artemisia judaica L.

\begin{tabular}{cccccc}
\hline $\mathbf{2 , 4 - D}$ & \multicolumn{5}{c}{ No. of subcultures } \\
$\left(\mathbf{m g ~ l}^{-\mathbf{1}}\right)$ & $\mathbf{1}$ & $\mathbf{2}$ & $\mathbf{3}$ & $\mathbf{4}$ & Means \\
\hline $\mathbf{0 . 0}$ & $0.00 \mathrm{~g}$ & $0.00 \mathrm{~g}$ & $0.00 \mathrm{~g}$ & $0.00 \mathrm{~g}$ & $0.00 \mathrm{C}$ \\
$\mathbf{1 . 0}$ & $0.65 \mathrm{f}$ & $4.47 \mathrm{e}$ & $13.17 \mathrm{~d}$ & $28.24 \mathrm{~b}$ & $11.64 \mathrm{~B}$ \\
$\mathbf{2 . 0}$ & $0.73 \mathrm{f}$ & $5.23 \mathrm{e}$ & $15.42 \mathrm{c}$ & $32.98 \mathrm{a}$ & $13.59 \mathrm{~A}$ \\
Means & $0.47 \mathrm{D}$ & $3.23 \mathrm{C}$ & $9.53 \mathrm{~B}$ & $20.40 \mathrm{~A}$ & \\
\hline
\end{tabular}

Table(6): Effect of the interaction between 2,4-D and kinetin (kin) concentrations on callus fresh weight (gm) of Artemisia judaica $\mathbf{L}$.

\begin{tabular}{cccccc}
\hline $\mathbf{2 , 4 - D}$ & Kin & \multicolumn{4}{c}{ No. of subcultures } \\
\cline { 3 - 6 }$\left(\mathbf{m g l}^{-1}\right)$ & $\left(\mathbf{m g ~ l}^{-1}\right)$ & $0.00 \mathrm{e}$ & $0.00 \mathrm{f}$ & $0.00 \mathrm{e}$ & $0.00 \mathrm{f}$ \\
& $\mathbf{0 . 0}$ & $0.00 \mathrm{e}$ & $0.00 \mathrm{f}$ & $0.00 \mathrm{e}$ & $0.00 \mathrm{f}$ \\
$\mathbf{0 . 0}$ & $\mathbf{0 . 1}$ & $0.00 \mathrm{e}$ & $0.00 \mathrm{f}$ & $0.00 \mathrm{e}$ & $0.00 \mathrm{f}$ \\
& $\mathbf{0 . 2}$ & $0.00 \mathrm{e}$ & $0.00 \mathrm{f}$ & $0.00 \mathrm{e}$ & $0.00 \mathrm{f}$ \\
& $\mathbf{0 . 3}$ & $0.65 \mathrm{c}$ & $4.47 \mathrm{be}$ & $13.17 \mathrm{c}$ & $28.24 \mathrm{~d}$ \\
\multirow{2}{*}{$\mathbf{1 . 0}$} & $\mathbf{0 . 0}$ & $0.68 \mathrm{bc}$ & $4.91 \mathrm{~b}-\mathrm{d}$ & $13.54 \mathrm{c}$ & $28.66 \mathrm{~cd}$ \\
& $\mathbf{0 . 1}$ & $0.72 \mathrm{~b}$ & $5.60 \mathrm{~b}$ & $15.70 \mathrm{~b}$ & $33.23 \mathrm{~b}$ \\
& $\mathbf{0 . 2}$ & $0.66 \mathrm{c}$ & $4.54 \mathrm{c}-\mathrm{e}$ & $13.33 \mathrm{c}$ & $28.34 \mathrm{~d}$ \\
\multirow{2}{*}{$\mathbf{2 . 0}$} & $\mathbf{0 . 3}$ & $0.73 \mathrm{~b}$ & $5.23 \mathrm{bc}$ & $15.42 \mathrm{~b}$ & $32.98 \mathrm{~b}$ \\
& $\mathbf{0 . 0}$ & $0.70 \mathrm{bc}$ & $5.11 \mathrm{~b}-\mathrm{d}$ & $15.21 \mathrm{~b}$ & $30.43 \mathrm{c}$ \\
& $\mathbf{0 . 1}$ & $0.81 \mathrm{a}$ & $6.34 \mathrm{a}$ & $18.23 \mathrm{a}$ & $35.12 \mathrm{a}$ \\
& $\mathbf{0 . 2}$ & $0.59 \mathrm{~d}$ & $3.88 \mathrm{e}$ & $11.34 \mathrm{~d}$ & $26.32 \mathrm{e}$ \\
\hline
\end{tabular}

Means having the same letter (s) within the same column are not significantly different according to Dunchan's multiple range test at $5 \%$ level of probability 
Table (7): Effect of the interaction between different kinetin (kin) and naphthalene acetic acid (NAA) concentrations on Artemisia judaica L. callus differentiation.

\begin{tabular}{cccccc}
\hline \multicolumn{2}{c}{ Growth regulators } & No. of & No. of & Shoot length & No. of \\
NAA & Kin & shoots/ & roots/ & (cm) & $\begin{array}{c}\text { leaves/ } \\
\text { shoot }\end{array}$ \\
$\left(\mathbf{m g l}^{-1}\right)$ & $\left(\mathbf{m g l}^{-1}\right)$ & calli & shoot & & $2.66 \mathrm{e}$ \\
\hline $\mathbf{0 . 0}$ & $\mathbf{0 . 0}$ & $1.33 \mathrm{~d}$ & $1.66 \mathrm{~d}$ & $2.11 \mathrm{e}$ & $4.11 \mathrm{~b}$ \\
& $\mathbf{0 . 1}$ & $1.99 \mathrm{c}$ & $2.00 \mathrm{c}$ & $2.66 \mathrm{c}$ & $4.66 \mathrm{a}$ \\
& $\mathbf{0 . 2}$ & $2.33 \mathrm{~b}$ & $2.33 \mathrm{bc}$ & $3.33 \mathrm{~b}$ & $3.33 \mathrm{~cd}$ \\
$\mathbf{1 . 0}$ & $\mathbf{0 . 0}$ & $2.33 \mathrm{~b}$ & $2.66 \mathrm{~b}$ & $2.88 \mathrm{c}$ & $3.44 \mathrm{c}$ \\
& $\mathbf{0 . 1}$ & $2.33 \mathrm{~b}$ & $2.66 \mathrm{~b}$ & $3.33 \mathrm{~b}$ & $4.00 \mathrm{~b}$ \\
& $\mathbf{0 . 2}$ & $2.66 \mathrm{a}$ & $3.00 \mathrm{a}$ & $3.50 \mathrm{a}$ & $3.88 \mathrm{c}$ \\
& $\mathbf{0 . 0}$ & $1.99 \mathrm{c}$ & $2.33 \mathrm{bc}$ & $2.50 \mathrm{~d}$ & $3.33 \mathrm{~cd}$ \\
& $\mathbf{0 . 1}$ & $1.80 \mathrm{c}$ & $2.50 \mathrm{~b}$ & $3.00 \mathrm{c}$ & $3.80 \mathrm{c}$ \\
\hline
\end{tabular}

Means having the same letter (s) within the same column are not significantly different according to Dunchan's multiple range test at $5 \%$ level of probability

Results showed that addition of NAA to the medium resulted in callus differentiation Table (7). The data indicate that NAA at $1.0 \mathrm{mgl}^{-1}$ gave the highest number of shoots per calli (2.33) while increasing the concentration to be $2 \mathrm{mgl}^{-1}$ depressed significantly the number of differentiated shoots.

Supplementation MS basal medium with 1.0 or $2.0 \mathrm{mgl}^{-1} \mathrm{NAA}$ alone produced significant increase in number of roots per shoot compared with control. There was no significant difference between both concentrations of NAA (1.0 and $2.0 \mathrm{mgl}^{-}$ $\left.{ }^{1}\right)$. Also, increasing NAA concentration significantly increased shoot length since addition of NAA at $2.0 \mathrm{mgl}^{-1}$ to the medium resulted in the highest shoot length $(3.33 \mathrm{~cm})$. Addition of NAA to the medium significantly increased the number of leaves on the shoot, without significant difference between low and high concentrations in this regard.
These results agreed with Husain and Mohammad (2006) findings on Eclipta alba L. since they found that the highest shoot regeneration frequency $(95 \%)$ as well as the maximum number $(32.2 \pm 0.4)$ of shoots was recorded on MS medium amended with BA $(5 \mu \mathrm{M})$ and $\operatorname{NAA}(0.5$ $\mu \mathrm{M})$.

The interaction between kin and NAA concentrations on differentiation of Artemisia judaica L. callus indicate that addition of NAA at $1.0 \mathrm{mgl}^{-1}$ combined with Kin at $0.2 \mathrm{mgl}^{-1}$ to the culture medium recorded the highest number of shoots and roots and shoot length to the culture medium $(2.66,3.00$ and 3.50 respectively) A similar result was obtained by Barna and Wakhiu (1988) since they found that, axillary shoot induction and plant regeneration in Plantago ovate Forssk was obtained on MS medium supplemented with $0.99 \mathrm{mgl}^{-1}$ Kin and $0.01 \mathrm{mgl}^{-1}$ NAA. Also, Mungole et al. (2009) developed an efficient 
micropropogation protocol for medicinal plant Ipomoea obscura L. by in vitro culture of nodal part of mature plant cultured on MS medium supplemented with $0.8 \mathrm{mgl}^{-1} \quad \mathrm{NAA}$ with $0.8 \mathrm{mgl}^{-1}$ kinetin which induced three shoots per node in an average and was the best for axillary bud proliferation.

Effect of auxin type, concentration and addition of activated charcoal on rooting of Artemisia judaica L. shoots during rooting stage:

Data in Table (8) cleared that in most cases indole-3-butyric acid (IBA) specially when combined with activated charcoal was significantly surpassed NAA and IAA in increasing all rooting parameters (rooting percentage, No. of roots/shoot and root length).

Also, in most cases addition of IBA at $1.5 \mathrm{mgl}^{-1}$ combined with $1.0 \mathrm{gl}^{-1}$ activated charcoal recorded the highest values of all rooting parameters (rooting percentage, No. of roots/shoot and root length) (94.6, 36.66 and 7.66 respectively). These results are generally in agreement with the findings of Liu et al. (2003 and 2004) since they reported that, regenerated shoots of Artemisia judaica L. were rooted successfully on MSO medium supplemented with $1 \mu \mathrm{mol}{ }^{-1}$ IBA.

Nathar and Yatoo (2014) on Artemisia pallens to induce rooting, individual elongated shoots after 40 days were cultured on MS media augmented with IAA, IBA or NAA mgl ${ }^{-1}$. They found that, the highest number of roots $(12 \pm 0.08)$ and the highest root length $(8.15 \pm 1.13$ $\mathrm{cm})$ were encountered with $3.0 \mathrm{mgl}^{-1}$ IBA. Concerning the enhancing effect of activated charcoal on rooting Abou Dahab et al. (2010) found that half strength WPM medium $+1.0 \mathrm{gml}^{-1}$ activated charcoal $+0.50 \mathrm{mgl}^{-1} \mathrm{IBA}$ was the best medium for in vitro rooting percentage and root number/shoot let for Taxodium distichumand Taxodium distichum var. 'distichum'.

Also, Sudipta et al. (2011) observed that maximum number of roots for Leptadenia reticulate was recorded when grown shoots were cultured on full strength MS media containing $2.00 \mathrm{mgl}^{-1}$ IBA combined with $200 \mathrm{mgl}^{-1}$ activated charcoal.

Finally, it is worth to mention that rooted plantlets were ex vitro acclimatized (90\% survival) when cultured in peat moss and sand (3:1, v/v) before transferred to soil and successfully grown in the open field.

\section{REFERENCES}

Abou Dahab, A. M.; A. M. Habib; M. K. El-Bahr and A. M. M. Gabr (2010). Establishment of an in vitro propagation protocol for Taxodium distichum and Taxodium distichum var, 'distichum'. Nature and Science. 8(9):216 - 227.

Ahmed, A. A.; T. Gouthaman; A.S. Rao and M.V. Rao (2005). Micropropagation of Phyla nodiflora L. Greene: an important medicinal plant. Iranian J. of Bio. 3 (3):186-190.

Alasania, N.; S. Manjgaladze; N.Lomtatidze and S. Tskvitinidze (2007). Effect of different growth media on in vitro propagation of grapevine cultivar "Chkhaveri" .Bull. Georg. Natl. Acad. Sci. 175(3): 94-95.

Azza, A. T. and G. Noga (2002). Cumin regeneration from seedling derived embryogenic callus in response to amended kinetin. Plant Cell, Tiss. Org. Cult. 69: 35- 40. 
Table (8): Effect of auxin type, concentration and activated charcoal concentration on rooting of Artemisia judaica $\mathrm{L}$. shoot during rooting stage.

\begin{tabular}{|c|c|c|c|c|c|c|c|}
\hline & & \multicolumn{2}{|c|}{$\begin{array}{c}\text { Rooting } \\
\text { percentage }\end{array}$} & \multicolumn{2}{|c|}{$\begin{array}{c}\text { No. } \\
\text { of roots/shoot }\end{array}$} & \multicolumn{2}{|c|}{$\begin{array}{r}\text { Root length } \\
\text { (cm) }\end{array}$} \\
\hline \multirow{2}{*}{\multicolumn{2}{|c|}{$\begin{array}{l}\text { Auxin } \\
\left(\mathrm{mgl}^{-1}\right)\end{array}$}} & \multicolumn{6}{|c|}{ Activated charcoal $\left(\mathrm{gml}^{-1}\right)$} \\
\hline & & 0.0 & 1.0 & 0.0 & 1.0 & 0.0 & 1.0 \\
\hline \multicolumn{2}{|c|}{0.0} & $55.6 \mathrm{v}$ & $62.6 \mathrm{~s}$ & $4.33 \mathrm{q}$ & 9.33 o & $2.00 \mathrm{j}$ & $4.33 \mathrm{gh}$ \\
\hline \multirow{3}{*}{ IAA } & 0.5 & $59.0 \mathrm{u}$ & $73.0 \mathrm{n}$ & $6.33 \mathrm{p}$ & $16.00 \mathrm{k}$ & $2.66 \mathrm{ij}$ & $5.66 \mathrm{~d}-\mathrm{f}$ \\
\hline & 1.0 & $61.6 \mathrm{t}$ & $78.3 \mathrm{k}$ & $10.33 \mathrm{~m}$ & $20.00 \mathrm{i}$ & $3.00 \mathrm{ij}$ & $6.33 \mathrm{~cd}$ \\
\hline & 1.5 & $66.6 \mathrm{q}$ & $84.0 \mathrm{~h}$ & $14.66 \mathrm{k}$ & $23.33 \mathrm{~g}$ & $2.66 \mathrm{ij}$ & $5.66 \mathrm{~d}-\mathrm{f}$ \\
\hline \multirow{5}{*}{ IBA } & 2.0 & $53.3 \mathrm{w}$ & $65.3 \mathrm{r}$ & $11.33 \mathrm{k}$ & $20.33 \mathrm{i}$ & $2.66 \mathrm{ij}$ & $5.66 \mathrm{~d}-\mathrm{f}$ \\
\hline & 0.5 & $89.3 \mathrm{~d}$ & $91.3 \mathrm{c}$ & 25.66d-f & $27.33 \mathrm{e}$ & $5.00 \mathrm{e}-\mathrm{g}$ & $7.33 \mathrm{bc}$ \\
\hline & 1.0 & $86.0 \mathrm{~g}$ & $88.0 \mathrm{e}$ & $27.33 \mathrm{c}$ & $29.66 \mathrm{~d}$ & $6.00 \mathrm{de}$ & $8.33 \mathrm{a}$ \\
\hline & 1.5 & $93.3 \mathrm{~b}$ & $94.6 \mathrm{a}$ & $33.66 \mathrm{a}$ & $36.66 \mathrm{a}$ & $5.66 \mathrm{~d}-\mathrm{f}$ & $7.66 \mathrm{ab}$ \\
\hline & 2.0 & $88.6 \mathrm{de}$ & $89.3 \mathrm{~d}$ & $29.66 \mathrm{~b}$ & $31.66 \mathrm{c}$ & $4.66 \mathrm{fg}$ & $6.66 \mathrm{~b}-\mathrm{d}$ \\
\hline \multirow{4}{*}{ NAA } & 0.5 & $75.0 \mathrm{~m}$ & 77.01 & $16.00 \mathrm{j}$ & $18.00 \mathrm{j}$ & $3.66 \mathrm{hi}$ & $6.66 \mathrm{~b}-\mathrm{d}$ \\
\hline & 1.0 & $81.6 \mathrm{j}$ & $82.6 \mathrm{i}$ & $20.00 \mathrm{~h}$ & $22.00 \mathrm{~h}$ & $4.33 \mathrm{gh}$ & $7.33 \mathrm{bc}$ \\
\hline & 1.5 & $87.0 \mathrm{f}$ & $88.0 \mathrm{e}$ & $23.33 \mathrm{~g}$ & $23.33 \mathrm{~g}$ & $3.66 \mathrm{hi}$ & $6.66 \mathrm{~b}-\mathrm{d}$ \\
\hline & 2.0 & $68.3 \mathrm{p}$ & $70.0 \mathrm{o}$ & $19.33 \mathrm{i}$ & $21.33 \mathrm{~h}$ & $3.00 \mathrm{ij}$ & $6.00 \mathrm{de}$ \\
\hline
\end{tabular}

Means having the same letter (s) within the same column are not significantly different according to Dunchan's multiple range test at $5 \%$ level of probability

Barna, K. S. and A. K. Wakhiu (1988). Axillary shoot induction and plant regeneration in Plantago ovate Forssk. Plant Cell, Tiss. Org. Cult. 15: 169-173.

Bown. D. (1995). Encyclopaedia of Herbs and their Uses. Dorling Kindersley, London. ISBN 0-7513-020-31.

Chee, R. and R. M. Pool (1987). Improved inorganic media constituents for in vitro shoot multiplication of vitis. Scienita Horticulture 32:85 - 95.

Duncan, B. D. (1955). Multiple range and multiple F test. Biometrics. 11:1- 42.
Facciola. S.(1990). A Source Book of Edible Plants. Kampong Publications ISBN 09628087-0-9 Excellent.

Faisal, M.; I. Siddique and M. Anis (2006). An efficient plant regeneration system for Mucuna pruriens L. (DC.) using cotyledonary node explants. In Vitro Cellular and Developmental Biology Plant 42(1): 59-64.

Gamborg, O.L.; R.A. Miller and K. Ojima (1968). Nutrient requirements of suspension cultures of soybean root cells. Exp. Cell Res. 50:151-158. 
Halaweish, F.T. and D.W. Tallamy (1998). Production of cucurbitacins by cucurbit cell cultures. Plant Sci. 131: 209-218.

Hassanein, R.A.; M.F. Gabr; A.M. Ahmed and Ghada A. Hegazi (2008). Micropropagation of Cappariscartilaginea Decne. Catrina J. 3(3): 30-35.

He, M.; Q. Shu-yuan and H. Lan-juan (2005). Rapid in vitro propagation of medicinally important plant Aquilaria agallocha. J. Zhejiang Univ Sci. 6B (8): 849-852.

Hristova, L.; A.E. Damyanova; Z. Doichinova and K. Totevav (2013). Effect of 6-Benzylaminopurine on micropropagation of Artemisia Chamaemelifolia Vill. (Asteraceae). Bulgarian J. of Agric. Sci. 19 (2): 57 60.

Huang, L. C. and T. Murashige (1976). Plant tissue culture media: major constituents, their preparation and some application. TCA Manual, 3 (1):539548.

Husain, M.K and A. Mohammad (2006). Rapid in vitro propagation of Eclipta alba (L.) Hassk by shoot tip culture. J. of Plant Biochemistry and Biotechnology 15(2): 147-149.

Huxley, A. (1992). The New RHS Dictionary of Gardening. MacMillan Press ISBN 0-333-47494-5.

Liu, C.Z.; Murch S. J.; M. EL-Demerdash and P. K. Saxena (2003). Regeneration of the Egyptian medicinal plant Artemisia judaica L. Plant Cell Rep 21: 525-530.

Liu, C.Z.; Murch S.J.; M. EL-Demerdash and P. K. Saxena (2004) Artemisia judaica L.: micropropagation and antioxidant activity. J. of Biotechnology 110: 63-71.
Lloyd, G. and B. McCowen (1980). Commercially feasible micropropagation of mountain laurel Kalmia latifolia by use of shoot- tip culture. Int. Plant Prop. Soc. Proc. 30: 421.

Michigan State University (1983). MSTAT-C Micro Computer Statistical Program, Version 2. Michigan State University, East Lansing.

Mungole, A.; R. Awati; S. Dey; A. Chaturvedi and P. Zanwar (2009). Invitro callus induction and shoot regeneration in Ipomoea obscura L.: potent Indian medicinal plant. Indian J. of Sci. and Tech. 2 (8): 24-26.

Murashige, T. and F. Skoog (1962). A revised medium for rapid growth and bioassays with tobacco tissue. Physiol. Plant 15: 473-497.

Nathar V.N. and G.M. Yato (2014). Micropropagation of an antidiabetic medicinal plant, Artemisia pallens. Turk. J. Bot. 38: 491-498.

Ndoye, M.; I. Diallo and Y. Gassama (2003). In vitro multiplication of semi arid forest tree Balanites aegyptiaca $\mathrm{L}$. Del. Affric. J. Biotech. 2 (11): 421-424.

Nishawy， E.E. (2008). Biotechnological studies on Thymus capitatus and Ajugaiva. M. Sc. Thesis, Fac. of Environmental Agricultural Sciences, Suez Canal Univ. El-Arish.

Nizar, A. (2001). Using plant tissue culture technique for rapid propagation. M.Sc. Thesis, Fac. Agric., Cairo University.

Romano, A. (1999). Callus induction and micropropagation of Dittrichia viscose L. Greuter Acta Hort. 502: 353-356 (C. f. Hort. Abst. (2000) 70(8): 961.

Shehata, S.A. (2005). Studies on some medicinal and aromatic plants using tissue culture technique. M. Sc. Thesis, Fac. of Environ. Agric. Sci., Suez Canal Univ., El-Arish. 
Sivanesan, I. (2007). Direct regeneration from apical bud explants of Withania somnifera Dunal. Indian J. of Bio., 6:125-127.

Sivanesan, I. and B. R. Jeong (2007). Micropropagation and in vitro flowering in Pentanemaindicum Ling. Plant Biotech. 24: 527-532.

Sudipta, K. M.; S. M. Kumara; S. Balasubramanya and M. Anuradha (2011). Cost effective approach for $i n$ vitro propagation of (Leptadenia reticulate Wight \& Arn.) -a threatened plant of medicinal important. journal of Phytology. 3(2):72-79.

Thao, N.T. P.; Y. Ozaki and H. Okubo (2003). Callus induction and plantlet regeneration in ornamental Alocasia michlitziana. Plant Cell, Tiss. Org. Cult. 73:285-289. 


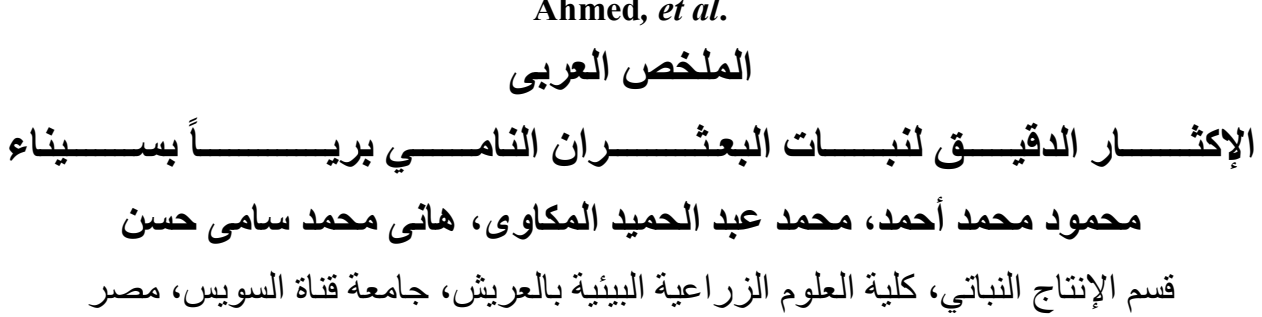

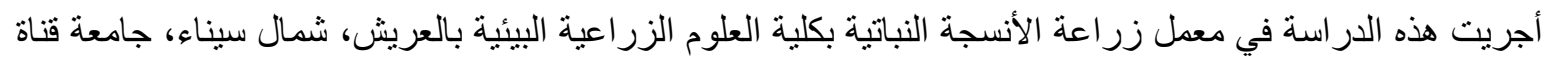

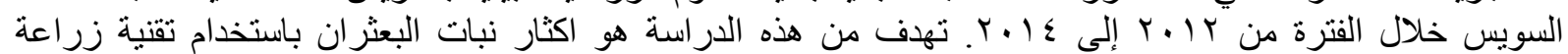

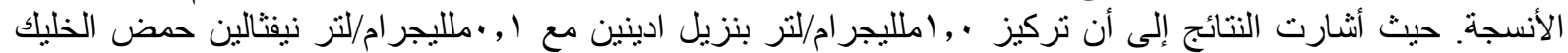

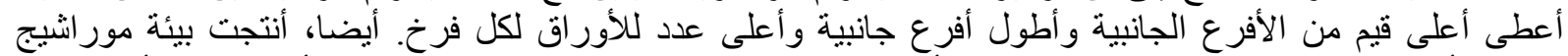

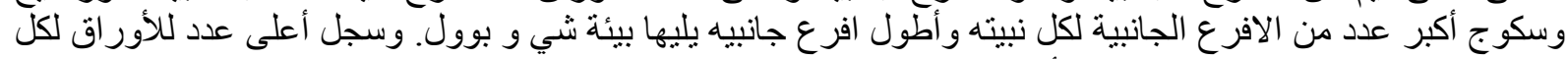

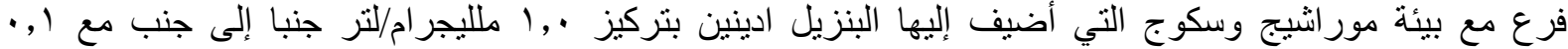

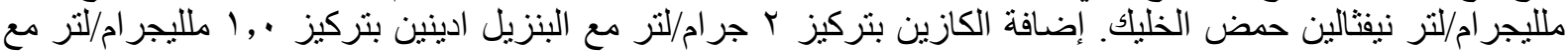

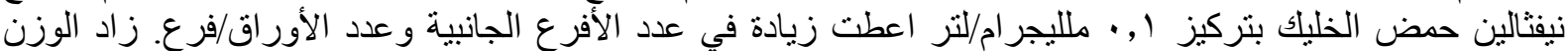

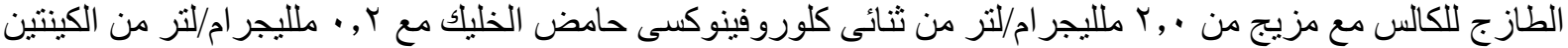

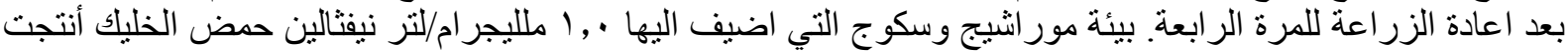

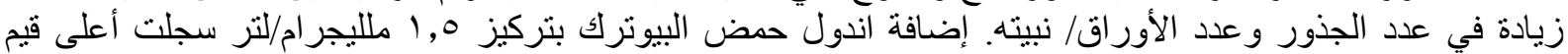

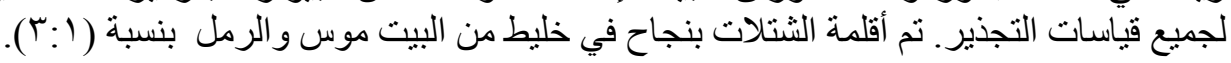
الكلمات الاسترشادية: الإكثار الاقيق، نبات البعثران، حمض الخليك، البنزيل ادينين، بيئة مور اشيج وسكوج. 